\title{
Living (stained) calcareous benthic foraminifera from recent sediments off Concepción, central-southern Chile $\left(\sim 36^{\circ} \mathrm{S}\right)$
}

\author{
Foraminíferos bentónicos calcáreos vivos (teñidos) en sedimentos recientes de \\ Concepción, Chile centro-sur $\left(\sim 36^{\circ} \mathrm{S}\right)$
}

RAÚL TAPIA ${ }^{1,2}, *$, CARINA B. LANGE ${ }^{2,3} \&$ MARGARITA MARCHANT ${ }^{4}$

\author{
${ }^{1}$ Programa de Postgrado en Oceanografía, Departamento de Oceanografía, Universidad de Concepción, \\ Casilla 160-C, Concepción, Chile \\ ${ }^{2}$ Centro de Investigación Oceanográfica en el Pacífico Sur-Oriental (FONDAP-COPAS), Universidad de Concepción, \\ Casilla 160-C, Concepción, Chile \\ ${ }^{3}$ Departamento de Oceanografía, Universidad de Concepción, Casilla 160-C, Concepción, Chile \\ ${ }^{4}$ Departamento de Zoología, Universidad de Concepción, Casilla 160-C, Concepción, Chile \\ *e-mail for correspondenc: rtapia@udec.cl
}

\begin{abstract}
This study examines onshore-offshore and vertical distribution of living (Rose Bengal stained) benthic foraminifera (>180 $\mu \mathrm{m}$ fraction) from three sediment stations along a bathymetric transect off Concepción, Chile (station $18=88 \mathrm{~m}$ water depth, station $26=120 \mathrm{~m}$, station $40=1,030 \mathrm{~m}$ ), within and below the oxygen minimum zone. All cores were collected in austral winter. Calcareous foraminifera dominated the three stations. The species composition, living foraminifera density, and vertical distribution patterns within the sediment changed in accordance with bottom water dissolved oxygen concentration and food availability. Onshore-offshore pattern revealed overall highest living foraminiferal densities at shelf stations 18 and 26 where bottom water dissolved oxygen was lowest $\left(\sim 0.2 \mathrm{~mL}^{-1}\right)$ and content in labile organic matter highest. Within the sediment, maximum relative abundances (50-60\%) of living organisms were found in the $0-1 \mathrm{~cm}$ interval at the organic-rich and oxygen-poor shelf stations 18 and 26. In the well-oxygenated $\left(2.7 \mathrm{~mL}^{-1}\right)$ slope station $40,70 \%$ of living foraminifera were observed deeper than the first centimeter. The number of species and the contribution of the $>250 \mu \mathrm{m}$ fraction to the total fauna larger than $180 \mu \mathrm{m}$ increased offshore. Nonionella auris (d'Orbigny) dominated at stations 18 and 26 while a more diverse foraminifera fauna was found at station 40 . This study provides the first quantitative data on living benthic foraminifera in the area; seasonal and interannual changes are not addressed.
\end{abstract}

Key words: benthic foraminifera, sediments, oxygen minimum zone, Concepción, Chile.

\section{RESUMEN}

Este estudio examina la distribución costa-océano y vertical de los foraminíferos bentónicos calcáreos (fracción $>180 \mu \mathrm{m}$ ) vivos (teñidos) en tres estaciones a lo largo de un transecto batimétrico frente al área de Concepción, Chile (estación $18=88 \mathrm{~m}$, estación $26=120 \mathrm{~m}$, estación $40=1.030 \mathrm{~m}$ de profundidad), dentro y bajo la zona mínima de oxígeno. Todos los testigos de sedimento fueron recolectados durante el período de invierno. Los foraminíferos calcáreos dominaron las tres estaciones. La composición específica, distribución vertical y abundancia de foraminíferos bentónicos vivos variaron en concordancia con el contenido de oxígeno disuelto del agua de fondo y la disponibilidad de materia orgánica. El patrón batimétrico reveló una mayor densidad de de foraminíferos vivos en las estaciones 18 y 26 donde el oxígeno disuelto de las aguas de fondo fue menor $\left(\sim 0,2 \mathrm{~mL}^{-1}\right)$ y la materia orgánica lábil mayor. Dentro del sedimento, las máximas abundancias relativas (50-60 \%) de foraminíferos vivos fueron encontrados en el intervalo 0-1 cm en las estaciones 18 y 26 ricas en materia orgánica y pobremente oxigenadas. En la bien oxigenada $\left(2,7 \mathrm{~mL}^{-1}\right)$ estación 40 , el $70 \%$ de los foraminíferos vivos se ubicaron por debajo del primer centímetro. El número de especies y la contribución de la fracción $>250 \mu \mathrm{m}$ se incrementaron costa afuera. Nonionella auris (d'Orbigny) fue la especie dominante en las estaciones 18 y 26, mientras que una fauna más rica se observó en la estación 40. Este estudio proporciona los primeros datos generales acerca de la distribución de foraminíferos bentónicos vivos en el área, sin apuntar a cambios estacionales y/o interanuales.

Palabras clave: foraminíferos bentónicos, sedimentos, zona de mínimo oxigeno, Concepción, Chile. 


\section{INTRODUCTION}

The vertical distribution of benthic foraminifers in the sediment column seems to be determined mainly by two factors: food availability and oxygen content at the seafloor (Gooday \& Rathburn 1999, Gooday 2003). This is supported by a number of field studies and experiments that demonstrate the effects of organic supply and changes in bottom water oxygen concentration on the microhabitat selection (e.g., Rathburn \& Corliss 1994, Ernst \& van der Zwaan 2004).

All these observations were summarized in the "TROX-model" of Jorissen et al. (1995), which relates the microhabitat "selection" of a given taxa to a balance between food and oxygen availability. According to this model, oligotrophic systems are food-limited and organisms are concentrated close to the sediment surface, where the majority of the food is located. Although eutrophic systems are oxygenlimited, organisms are also concentrated near the surface in order to avoid anoxic conditions deeper in the sediment. This general scheme has been refined by Jorissen (1999), van der Zwaan et al. (1999), and Fontanier et al. (2002) who suggested that: (1) the organic matter flux is the main parameter controlling foraminiferal microhabitats, (2) oxygen is not the limiting factor for deep infaunal species, and that (3) biological interactions, particularly competition for labile food material, may play a role in microhabitat selection.

Oxygen minimum zones (OMZs) are significant midwater features in the eastern Pacific Ocean (e.g., Helly \& Levin 2004). It has been shown that, where the OMZ intercepts the continental margin, strong gradients are formed in both bottom water dissolved oxygen concentrations and organic matter input (Levin et al. 2000). These gradients influence the biogeochemical properties of the underlying sediments and the distribution of benthic organisms within the sedimentary column. Usually organic-rich, oxygen-poor environments are dominated by meiofauna, mainly calcareous foraminifera and nematodes (e.g., Levin et al. 2002). In the last decades, significant advances have been made in the understanding of ecological aspects of benthic foraminifera from oxygen deficient settings in the world (see Bernhard \& Sen Gupta 1999 for a review), including off Peru in the eastern south Pacific (Phleger \& Soutar 1973, Levin et al. 2002).

Substantial progress in the knowledge of modern benthic foraminifera from the Chilean continental margin has been made since the early works of Bandy \& Rodolfo (1964), Boltovskoy \& Theyer (1970), and Ingle et al. (1980). More recent studies (e.g., Zapata \& Moyano 1997, Figueroa et al. 2005, 2006, Hromic et al. 2006) have focused on taxonomic and/or biogeographical aspects, emphasizing the identification and characterization of zoogeographic provinces along the Chilean coast. But none of these studies investigated the relationship between living benthic foraminiferal fauna and environmental characteristics.

To provide new insight into benthic foraminiferal ecology off Concepción, Chile ( $\left.36^{\circ} \mathrm{S}\right)$, we present results on total and living benthic foraminifera from a bathymetric transect $(80,120,1,030 \mathrm{~m}$ water depth; Table 1, Fig. 1A) that includes stations within (stations 18 and 26) and below the OMZ (statation 40). Our study focused on (1) onshore-offshore, and (2) vertical distribution of calcareous foraminiferal communities within the sedimentary column (upper $10 \mathrm{~cm}$ ) with regard to bottom water oxygen content and organic matter availability.

TABLE 1

Location and collection date of sampling sites

Localización de las estaciones y fechas de muestreo

\begin{tabular}{lccccc}
\hline Station & Core & Collection date & Latitude $(\mathrm{S})$ & Longitude $(\mathrm{W})$ & Water depth $(\mathrm{m})$ \\
\hline 18 & MUC1803 & 12 August 2003 & $36^{\circ} 30^{\prime}$ & $73^{\circ} 07^{\prime}$ & 88 \\
26 & MUC2603 & 12 August 2003 & $36^{\circ} 26^{\prime}$ & $73^{\circ} 23^{\prime}$ & 120 \\
40 & RC4004 & 10 August 2004 & $36^{\circ} 20^{\prime}$ & $73^{\circ} 44^{\prime}$ & 1.030 \\
\hline
\end{tabular}

MUC $=$ Multicorer, $\mathrm{RC}=$ Rhumor corer 

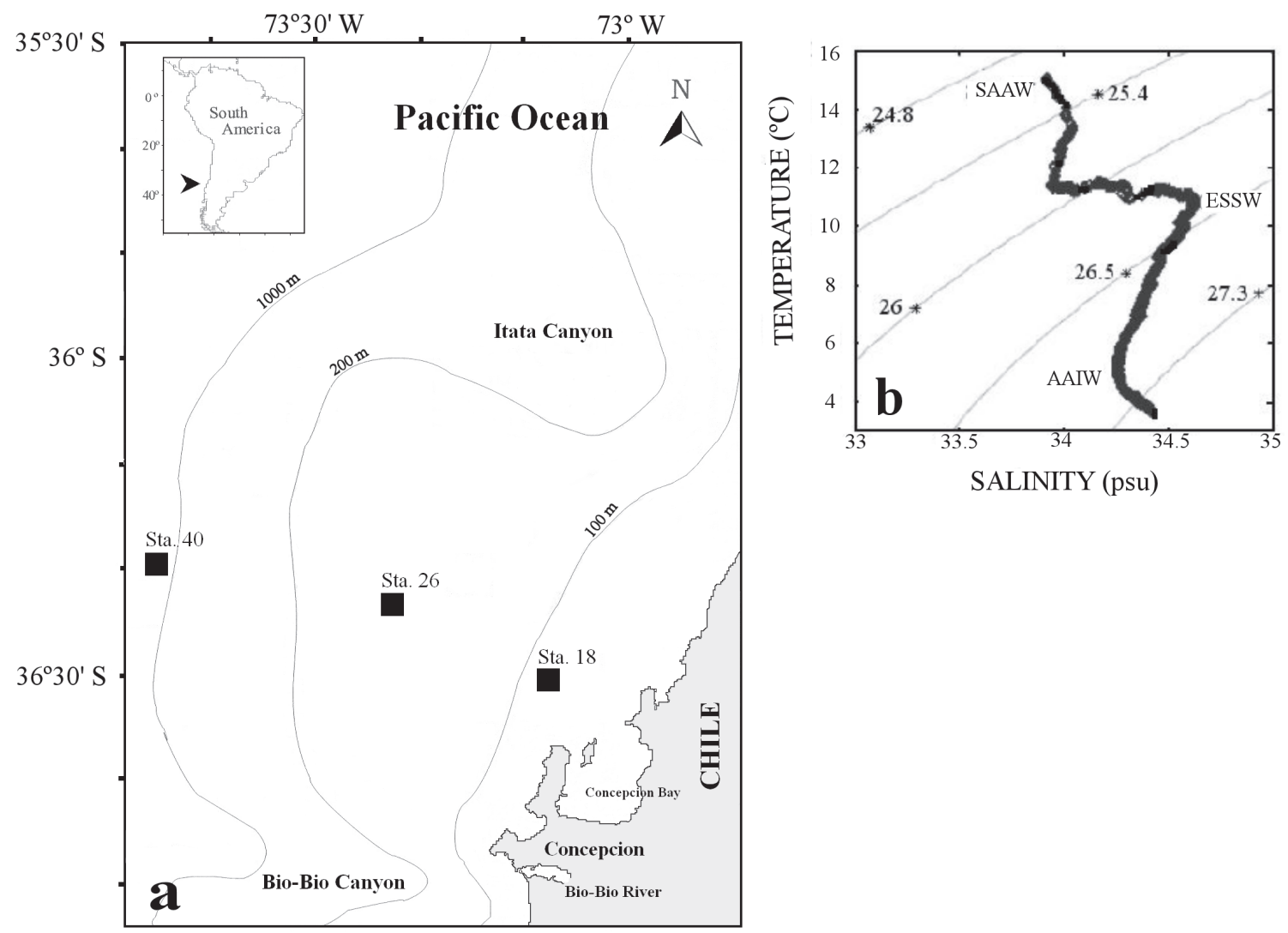

Fig.1: (A) Study area showing the position of the sampling stations off Concepción used in this study: station 18 (middle shelf), 26 (outer shelf), and 40 (on the middle slope), and bathymetry; (B) T-S diagram (April 2003) for station 40 showing the different water masses present: Subantarctic Water (SAAW), Equatorial Subsurface Water (ESSW), and Antarctic Intermediate Water (AAIW). See text for details.

(A) Área de estudio mostrando la posición de las estaciones de muestreo frente a Concepción utilizadas en este estudio: estaciones 18 (plataforma interior), 26 (plataforma exterior), y 40 (talud), y batimetría de la región; (B) diagrama T-S (abril 2003) para la estación 40 mostrando las diferentes masas de agua presentes: Agua Antárctica Superficial (SAAW), Agua Ecuatorial Subsuperficial (ESSW) y Agua Intermedia Antárctica (AAIW). Ver texto para detalles.

\section{Regional setting}

The area off central-southern Chile has been studied in detail by various authors (Ahumada \& Chuecas 1979, Sobarzo et al. 2001) including plankton variability, biogeochemical processes, and physical and chemical characteristics (Escribano \& Schneider 2007).

Due to diverse factors (coastal winds, upwelling events, shelf width, and topographic settings), this area is one of the most productive sectors of the central-southern Chilean coast (35-45 S, Shaffer et al. 1999) with primary productivity values among the highest in the world ocean (Daneri et al. 2000, Schubert et al. 2000). Upwelling is strongly seasonal. It intensifies during austral spring-summer, fertilizing the photic zone with the salty, nutrient-rich, oxygen-poor waters of the Equatorial Subsurface Water mass (ESSW) (Ahumada \& Chuecas 1979). Upwelled ESSW can be found over the continental shelf and sometimes even at the inner part of Concepción Bay. Downwelling usually occurs in winter due to the prevalence of strong northerly winds (Sobarzo 1993).

High phytoplankton biomass and primary production (reaching $19.9 \mathrm{~g} \mathrm{C} \mathrm{m}^{-2} \mathrm{~d}^{-1}$, Daneri et al. 2000) followed by high rates of organic matter sedimentation to the seafloor (e.g., Gutiérrez et al. 2000) promote anoxic/dysoxic conditions in the sediments (Neira et al. 2001). 
Total organic carbon content (TOC) in the sediment is usually high and varies between 2 and $5 \%$ (Table 2), with maximum TOC values in austral summer (Muñoz et al. 2007). Organic matter is mainly of phytoplanktonic origin (Schubert et al. 2000). Chlorophyll- $a$ (Chl-a) concentrations in the surface sediments clearly decrease offshore (Table 2). On a yearly basis, $\mathrm{C} / \mathrm{N}$ molar values fluctuate between 8.4 and 11.3 (Muñoz et al. 2007). Modern sedimentation rates are high $\left(0.09-0.25 \mathrm{~cm} \mathrm{yr}^{-1}\right.$, Muñoz et al. 2004). Sediments are usually composed of silt and clay minerals with a mean grain size of 8.5-13.0 $\mu \mathrm{m}$ (Molina et al. 2004).

The study area is located on the widest portion of the continental margin off centralsouthern Chile $(50 \mathrm{~km})$ (Fig. 1A). The shelf is limited by two submarine canyons and their corresponding rivers: the Itata canyon (Itata River) to the north and the Biobío canyon (BioBío River) to the south. In general, three different water masses can be observed here: Subantarctic Water (SAAW) between the surface and about $80 \mathrm{~m}$ depth, ESSW at about 80 to $400 \mathrm{~m}$ with minimum dissolved oxygen concentrations, and Antarctic Intermediate Water (AAIW) below $400 \mathrm{~m}$ (Molina et al. 2004) impinging on the continental slope (Fig. $1 \mathrm{~B})$. The OMZ is associated with oxygendepleted ESSW and intensifies by the local biogeochemical $\mathrm{O}_{2}$ consumption (Paulmier et al. 2006). Off Concepción, the OMZ is less intense and its upper boundaries are deeper (about $100 \mathrm{~m}$ ) than off northern Chile (Pizarro et al. 2002); its strength and the depth of the upper boundary vary seasonally. The OMZ's upper boundary is shallow in spring-summer (at $20 \mathrm{~m}$ from October to March) during the high upwelling activity period with $\mathrm{O}_{2}$ concentrations lower than $0.2 \mathrm{~mL}^{-1}$, but it deepens in autumn (about $50 \mathrm{~m}$ in April-May) (Paulmier et al. 2006).

\section{MATERIAL AND METHODS}

The sediment samples used in this study were collected during winter cruises as part of the COPAS Center Time Series Study off Concepción (Table 1). A SMBA-type minimulticorer (MUC) with six sampling tubes (inner diameter $=9.5 \mathrm{~cm}$ ) was used for sampling at Sta. 18 (middle shelf, $88 \mathrm{~m}$ water depth) and 26 (outer shelf, $120 \mathrm{~m}$ water depth) (Fig. 1A). A Rhumor corer (RC) - a type of gravity corer that recovers the sediment-water interface - was used at Sta. 40 (middle slope, $1,030 \mathrm{~m}$ water depth). The RC uses an acrylic of $7 \mathrm{~cm}$ internal diameter and $\sim 100 \mathrm{~cm}$ in length. One core tube was analyzed for each station. Due to the limited data set, interannual and seasonal changes cannot be addressed.

The cores were sliced at $0.5 \mathrm{~cm}$ intervals for the upper 2-3 cm, and every $1 \mathrm{~cm}$ downcore. Immediately after slicing, the samples were preserved and stained according to the methodology of Rathburn \& Corliss (1994); samples were allowed to stain for at least one week before processing for foraminifera analysis. Samples were not split but examined entirely for their content of live foraminifera. The use of Rose Bengal stained foraminifera to interpret living associations was critically discussed by Bernhard (1988). One problem of this technique is the fact that Rose Bengal may stain the protoplasm of dead foraminifera, which may be relatively well preserved under anoxic conditions leading to an overestimation of the living fauna. However, it is still the most frequently used method in foraminifera research and the most practical one (Bernhard 2000). Our definition of "stained" (living) foraminifera was very strict and only specimens with all chambers, except for the last one (the youngest) stained bright pink were counted as stained.

After staining, samples were wet-sieved using 63,180, and $250 \mu \mathrm{m}$ mesh-opening. The data presented here are from the $>250$ and 180 $250 \mu \mathrm{m}$ fractions and refer to the upper $10 \mathrm{~cm}$ of each core. The mesh sizes were selected in keeping with the methodology previously used for the COPAS Time Series Study off Concepción (Tapia 2003). The fraction 63-180 $\mu \mathrm{m}$ was preserved for future studies.

We are aware of the fact that the selection of the $>180 \mu \mathrm{m}$ size fraction may have introduced some bias regarding the abundance of total foraminifers as well as the abundance of smaller organisms. Although the smaller size fraction (e.g., 63-150 $\mu \mathrm{m}$ ) may contain a large number of foraminiferal species and juvenile forms that are rare or absent in the larger size fraction (e.g., Schröder et al. 1987), their removal is extremely time-consuming. Additionally, smaller specimens are often more problematic to identify to the species level. 
TABLE 2

Summary of available water column and surface sediment characteristics off Concepción

Resumen de la características de la columna de agua y sedimentos para el área frente a Concepción

\begin{tabular}{|c|c|c|c|c|c|c|}
\hline \multirow[t]{3}{*}{ Water column } & \multicolumn{6}{|c|}{ Station } \\
\hline & \multicolumn{2}{|c|}{$18(88 \mathrm{~m})$} & \multicolumn{2}{|c|}{$26(120 \mathrm{~m})$} & \multicolumn{2}{|c|}{$40(1,030 \mathrm{~m})$} \\
\hline & Summer & Winter & Summer & Winter & Summer & Winter \\
\hline Bottom water dissolved oxygen $\left(\mathrm{mlL}^{-1}\right)$ & $0.07^{1}$ & $0.45^{1}(0.17)^{\mathrm{a}}$ & $0.4^{2}$ & $0.6^{2}$ & $3.4^{1}$ & $2.9^{1}(2.7)^{b}$ \\
\hline Surface water temperature $\left({ }^{\circ} \mathrm{C}\right)$ & $13.3^{1}$ & $12.5^{1}(11.8)^{\mathrm{a}}$ & nd & $14.6^{1}$ & $12.3^{1}$ & \\
\hline Bottom water temperature $\left({ }^{\circ} \mathrm{C}\right)$ & $10.5^{1}$ & $10.8^{1}(11.2)^{\mathrm{a}}$ & $9.2^{2}$ & $11.6^{2}$ & $4.6^{1}$ & $4.0^{1}$ \\
\hline Surface water salinity (psu) & $32.2^{1}$ & $32.9^{1}(32.8)^{\mathrm{a}}$ & nd & $33.8^{1}$ & $34.7^{1}$ & \\
\hline Bottom water salinity (psu) & $34.6^{1}$ & $34.5^{1}(34.6)^{\mathrm{a}}$ & $35.9^{2}$ & $35.1^{2}$ & $34.2^{1}$ & $34.3^{1}$ \\
\hline Sediments & \multicolumn{2}{|c|}{ Middle shelf } & \multicolumn{2}{|c|}{ Outer shelf } & \multicolumn{2}{|c|}{ Middle slope } \\
\hline Chlorophyll- $a\left(\mu \mathrm{g} \mathrm{g}^{-1}\right) *$ & $24.1^{3}$ & $21.9^{3}(8.1)^{3}$ & $28.7^{2}$ & $27.9^{2}$ & $13.4^{4}$ & nd \\
\hline$\%$ TOC $*$ & $3.9^{3}$ & $3.3^{2}$ & $4.6^{2}$ & $5.1^{2}$ & $2.9^{5}$ & $2.1^{4}$ \\
\hline $\mathrm{Eh}(\mathrm{mV}) *$ & $120^{2}$ & $168^{2}$ & $176^{2}$ & $139^{2}$ & $257^{4}$ & nd \\
\hline
\end{tabular}

Sources: ${ }^{1}$ CTDO data (2002-2004) (http://copas.udec.cl/eng/research/timeseries.php) from COPAS Time-Series off Concepción averaged for summer and winter seasons; ${ }^{2}$ Gutiérrez (2000), includes data within the El Niño 1997-98 period; ${ }^{3}$ Muñoz et al. (2007); ${ }^{4}$ Gallardo et al. (2004); ${ }^{5}$ Böning et al. (2005). Data in parentheses refer to the sampling time of this study, based on CTDO profiles $\left(^{\text {a }}\right)$ or Niskin bottles $\left({ }^{b}\right)$; $(*)$ data for the first centimeter of sediment; nd = no data available. Bottom water oxygen and temperature measured at $80 \mathrm{~m}$ depth at station 18 , and at $750 \mathrm{~m}$ depth at Station 40

To our knowledge, there is only one quantitative (unpublished) study of living benthic foraminifera available for the shelf off Concepción (Mayor et al. unpublished results). Our results may have underestimated the total number of living foraminifera in the study area (shelf stations) by ca. $20 \%$ as compared with the abundances obtained by Mayor et al. (unpublished results) for the $>150 \mu \mathrm{m}$ fraction. However, the total numbers of benthic foraminifera (stained + dead) and species that we found for the slope area off Concepción falls within the range obtained by Figueroa et al. $(2005,2006)$ who analyzed the $>150 \mu \mathrm{m}$ at nearby slope and deep stations. An important aspect is that a scan of the $>63 \mu \mathrm{m}$ fraction revealed that, with the exception of tiny Globobulimina and Stanforthia, the overall species composition for the Concepción area is comparable in both small and coarser size fractions.

The total density of living calcareous foraminifera was determined by integrating the numbers of live individuals picked at all levels from 0 to $10 \mathrm{~cm}$ sediment depth. Percentages of individual taxa were calculated from the raw density data. Concerning vertical profiles, foraminiferal densities were normalized to 50 $\mathrm{cm}^{3}$ sediment volume for each 0.5 and $1 \mathrm{~cm}$ layer. Finally, with the purpose of comparison with other areas, living calcareous foraminifera were normalized to $50 \mathrm{~cm}^{2}$ for the first centimeter.

We assigned the benthic foraminifera to two different microhabitat groups (shallow and deep infauna). None of the species off Concepción could be considered to be strictly epifauna as defined by Buzas et al. (1993) who suggested that only species living on elevated substrates can be assigned to this category.

In order to provide an overview of the environmental characteristics in the study area, we present available water column and surface sediment data in Table 2; in those cases when environmental data were not available for the dates we collected the cores, we resorted to previously published data. Water column data derive mostly from the COPAS Time Series Study off Concepción (http://copas.udec.cl/eng/ research/timeseries.php), and include CTDO data (2002-2004) and/or data obtained from Niskin bottles (station 40). The sediment data stem from several sources (Gutiérrez 2000, Gallardo et al. 2004, Muñoz et al. 2007). 


\section{RESULTS}

The sediments off Concepción were typically greenish-brown in color $(7.5 \mathrm{Y} 3 / 2$ 7.5 Y 4/2 Munsell table color). Fecal pellets were numerous at the shallower stations (Sta. 18 and 26). A grey layer of very fine material was observed at 7-9 $\mathrm{cm}$ depth in the core from station 40. Available Chl- $\alpha$ and TOC data (although not always coincident with our August samplings) reveal that the sediments of the shelf stations are generally characterized by higher levels of Chl- $a$ concentrations and TOC ( $>20 \mu \mathrm{g} \mathrm{g}^{-1}$ and $>3.3 \%$, respectively) than the slope station 40 (Table 2). Bottom water dissolved oxygen (BWDO) conditions differed along the transect. Minimum BWDO values $\left(0.17 \mathrm{~mL}^{-1}\right)$ were encountered at station 18 (88 m water depth) and maximum values at station $40\left(2.7 \mathrm{~mL}^{-1}\right)$ during our August samplings (Table 2), in agreement with known OMZ boundaries in the area. Redox potential values at the sediment surface (Eh) agree with increasing bottom water dissolved oxygen concentrations from onshore to offshore (Table 2).

Using the BWDO values given in Table 2, the stations could be grouped into two categories according to Sen Gupta \& MachainCastillo (1993) classification of environments: (1) shelf stations 18 and 26, with dysoxicsuboxic conditions $\left(<2 \mathrm{~mL}^{-1}\right)$, located at and immediately below the upper boundary of the OMZ, respectively; and (2) slope station 40, with oxygenated conditions $\left(>2 \mathrm{~mL}^{-1}\right)$, located several hundred meters below the OMZ Bottom water temperature, salinity, and BWDO (Table 2) showed the influence of the ESSW at Sta. 18 and 26, whereas AAIW affected Sta. 40.

\section{Onshore-offshore distribution of benthic foraminifera}

The analysis of benthic foraminifera in the cores off Concepción showed that the contribution of the $>250 \mu \mathrm{m}$ fraction to the total fauna (larger than $180 \mu \mathrm{m}$ ) increased offshore (Table 3 ) from $1.8 \%(88 \mathrm{~m}$ ) to $16 \%$ $(120 \mathrm{~m})$ and $29 \%$ (1030 m water depth).

At all three stations, rotalid foraminifera were the main component of the total benthic foraminiferal fauna $(>75 \%)$. Agglutinated foraminifera were very rare $(0.4 \%)$ at Sta. 18 but reached 8 and $16 \%$ of the total fauna at station 26 and 40, respectively. Miliolids were only present at station $40(\sim 1 \%)$ (Table 3$)$.

TABLE 3

Size range of benthic foraminifera, relative abundance of the three main groups (Agglutinated, Rotalid and Miliolid in the $>180 \mu \mathrm{m}$ fraction), total number of living species, percentage of living calcareous foraminifera with respect to total benthic foraminifera, and total benthic foraminifera

(> $180 \mu \mathrm{m}$, calcareous + agglutinated) within the upper $10 \mathrm{~cm}$ of each core at stations 18,26 and 40 . Totals are standardized to $50 \mathrm{~cm}^{2}$ surface area and $10 \mathrm{~cm}$ sediment depth

Rango de tamaño de los foraminíferos bentónicos, abundancia relativa de los tres principales grupos (Aglutinados,

Rotalidos y Miliolidos en la fracción $>180 \mu \mathrm{m}$ ), número de especies vivas, porcentaje de foraminíferos bentónicos calcáreos vivos con respecto al total de bentónicos, y foraminíferos bentónicos totales (>180 $\mu \mathrm{m}$, calcáreos + aglutinados $)$ dentro de los primeros $10 \mathrm{~cm}$ de cada testigo de sedimento para las estaciones 18, 26 y 40. Los totales están estandarizados a $50 \mathrm{~cm}^{2}$ de superficie y $10 \mathrm{~cm}$ de profundidad de sedimento

\begin{tabular}{|c|c|c|c|c|}
\hline Characteristic & & Station $18(88 \mathrm{~m})$ & Station $26(120 \mathrm{~m})$ & Station $40(1,030 \mathrm{~m})$ \\
\hline \multirow[t]{2}{*}{ Size range } & $>250^{\prime} \mu \mathrm{m}(\%)$ & 1.8 & 16 & 29 \\
\hline & $250-180 \mu \mathrm{m}(\%)$ & 98.2 & 84 & 62 \\
\hline \multirow[t]{4}{*}{ Main groups } & Rotalid foraminifera $(\%)$ & 99.6 & 92 & 83 \\
\hline & Agglutinated foraminifera $(\%)$ & 0.4 & 8 & 16 \\
\hline & Miliolid foraminifera (\%) & 0 & 0 & $\sim 1$ \\
\hline & Total number of living species & 3 & 10 & 18 \\
\hline \multirow[t]{2}{*}{ Percentage of living } & Living calcareous foraminifera $(\%)$ & 60 & 18 & 7 \\
\hline & Total benthic foraminifera & 615 & 1,904 & 5,252 \\
\hline
\end{tabular}


Table 4 provides the listing of all living benthic foraminifera species found in this study. Stations 18 and 26 shared the same live calcareous assemblage. Both stations were characterized by the dominance of Nonionella auris (d'Orbigny), which made up $>90 \%$ of the total fauna of stained calcareous foraminifera (Table 5). In contrast, foraminiferal live assemblage at station 40 strongly differed. Here, Bolivina spissa Cushman, Globobulimina affinis (d'Orbigny), Chilostomella oolina Schwager, and Uvigerina peregrina Cushman were the most relevant taxa (Table 5).

The relative abundance of stained calcareous foraminifera ( $>180 \mu \mathrm{m}$, Table 3$)$ as well as their densities within the first centimeter (Table 6) decreased drastically from shelf to slope (i.e., from 161-198 at shelf stations 18 and 26 to 96 specimens per $50 \mathrm{~cm}^{2}$ at Sta. 40).

Downcore pattern and microhabitat of benthic foraminifer species

Stations 18 and 26 showed the highest concentrations of stained organisms near the sediment surface (Fig. 2); indeed, 50 and $60 \%$ (cumulative percent) of total living calcareous foraminifera were observed within the first centimeter at each station. In contrast, station 40 contained only $30 \%$ of the total stained calcareous foraminifera at the surface, and a maximum was observed at $1-1.5 \mathrm{~cm}(\sim 22 \%$ of total living calcareous foraminifera) (Fig. 2). In addition, minor secondary abundance peaks were observed at station 18 and 40 between 5-6 $\mathrm{cm}(\sim 5 \%)$ and $3-4 \mathrm{~cm}(\sim 9 \%)$, respectively (Fig. 2).

Identification of species microhabitat was based on the presence or absence of an infaunal maximum, and on the shape of the distribution profile of each species (position with respect to other taxa; Fig. 3). Based on these assumptions, we defined the species $N$. auris, B. spissa, $U$. peregrine, $B$. seminuda and $B$. costata as shallow infauna, and $G$. affinis and $C$. oolina as deep infauna. The high abundance of shallow infauna and the absence of deep infauna characterized the shelf stations located under the OMZ's influence (station 18 and 26). In contrast, shallow and deep infaunal species were observed at the slope station $40(1,030 \mathrm{~m}$ water depth).

TABLE 4

Living (stained) benthic foraminifers identified in this study

Foraminíferos bentónicos vivos (teñidos) identificados en este estudio

Bolivina costata d'Orbigny, 1839.

Bolivina plicata d'Orbigny, 1839.

Bolivina seminuda Cushman = Bolivina seminuda var. humilis Cushman and McCulloch, 1942 .

Bolivina spissa Cushman = Bolivina subadvena Chusman var. spissa Chusman, 1926.

Bulimina denudata Cushman and Parker, 1938.

Cassidulina limbata Cushman and Hughes 1925.

Chilostomella oolina Schwager 1878.

Cibicidoides wuellerstorfi (Schwager, 1866) = Cibicidoides wuellerstorfi Resig ,1981.

Dentalina communis (d'Orbigny) = Nodosaria (Dentilina) communis d'Orbigny, 1826.

Epistominella pacifica $($ Cushman $)=$ Pulvinulinella pacifica Cushman, 1927.

Gyrodinoides neosoldanii $($ Brotzen) = Gyroidina neosoldani Ingle et al., 1980 .

Globobulimina affinis (d'Orbigny) = Bulimina affinis d'Orbigny, 1839 .

Martinottiella communis (d'Orbigny) = Clavulina communis d'Orbigny, 1826.

Melonis barleeanum (Williamson) = Nonionina barleeana Williamson, 1858 .

Nonionella auris (d'Orbigny) = Valvulina auris d'Orbigny, 1839.

Pyrgo murrhina $($ Schwager, 1866) = Pyrgo murrhyna Resig, 1981.

Sacammina atlantica $($ Cushman $)=$ Proteonina atlantica Cushman, 1944.

Uvigerina peregrina Cushman, 1923. 


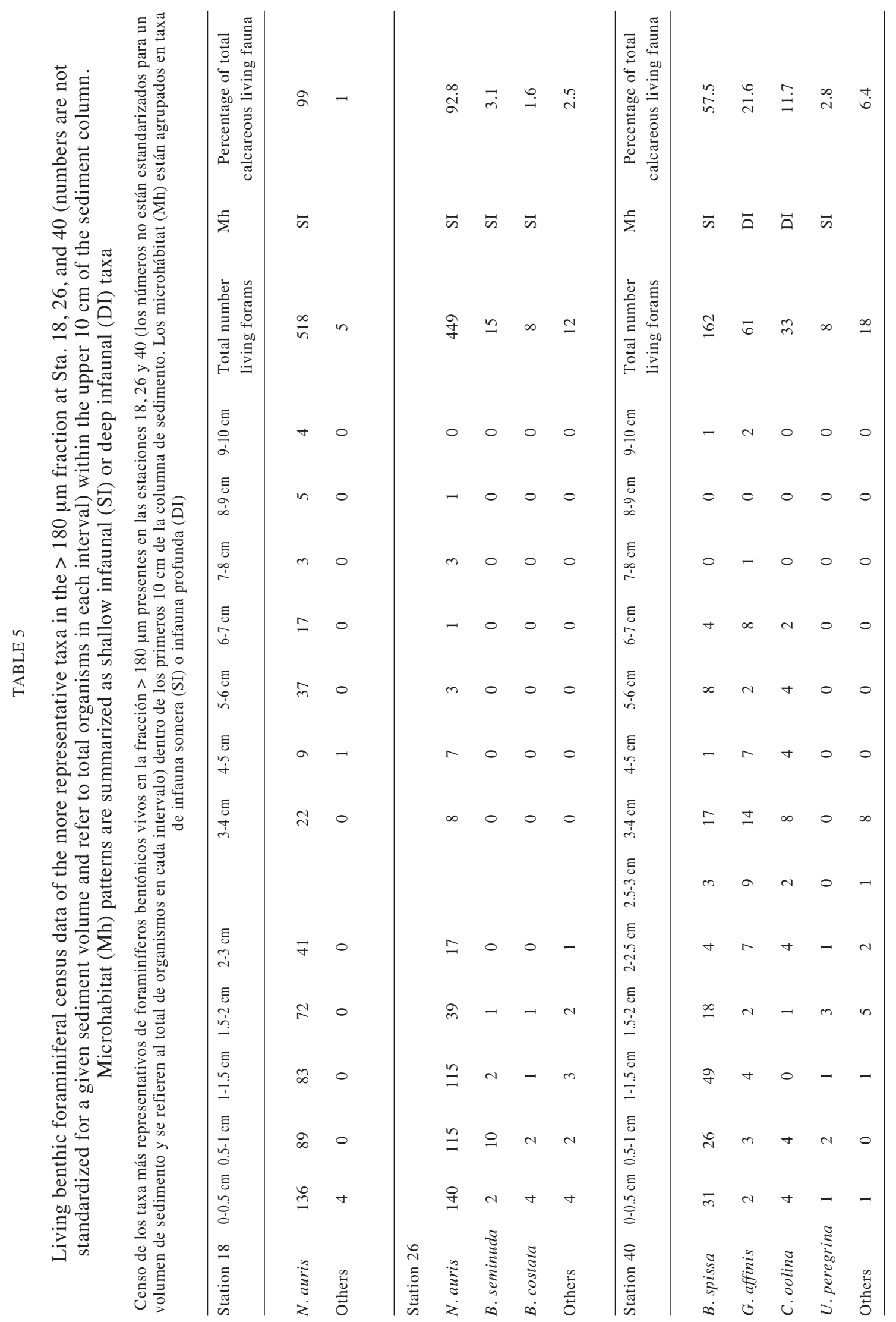


TABLE 6

Number of species and density data for living (stained) benthic foraminifera from low-oxygen environments (modified from Gooday 2003), compared to our study area. ND = no data

Número de especies y densidad de foraminíferos bentónicos vivos (teñidos) de ambientes pobres en oxígeno (modificado de Gooday 2003) comparados con nuestra área de estudio. ND = sin datos

\begin{tabular}{|c|c|c|c|c|}
\hline Site and depth & WWO $\left(\mathrm{mL}^{-1}\right)$ & $\begin{array}{l}\text { Number } \\
\text { of species }\end{array}$ & $\begin{array}{l}\text { Stained specimens } \\
\text { per } 50 \mathrm{~cm}^{2}\end{array}$ & $\begin{array}{l}\text { Reference; size fraction and } \\
\text { horizon examined }\end{array}$ \\
\hline \multicolumn{3}{|l|}{ Oman margin } & & Gooday et al. (2000)> $63 \mu \mathrm{m}, 0-1 \mathrm{~cm}$ \\
\hline $412 \mathrm{~m}$ & 0.13 & 64 & 65,535 & \\
\hline $3,350 \mathrm{~m}$ & $\sim 3.00$ & 208 & 2,930 & \\
\hline \multicolumn{3}{|l|}{ Santa Barbara basin } & & hleger \& Soutar $(1973)>62 \mu \mathrm{m}$, surface sediment \\
\hline $575 \mathrm{~m}$ & $\sim 0.1$ & $\sim 13$ & 5,875 & \\
\hline $590 \mathrm{~m}$ & $\sim 0.1$ & ND & 5,250 & \\
\hline \multicolumn{3}{|l|}{ Santa Barbara basin } & & Bernhard $(1990)>63 \mu \mathrm{m}, 0-1 \mathrm{~cm}$ \\
\hline 486 m (Feb 1988) & $\sim 0.11$ & ND & 2,660 & \\
\hline $550 \mathrm{~m}$ (June 1888) & $<0.1$ & ND & 34,505 & \\
\hline $550 \mathrm{~m}(\mathrm{Feb} 1988)$ & $<0.1$ & ND & 21,700 & \\
\hline $550 \mathrm{~m}$ (June 1988) & $<0.1$ & ND & 47,785 & \\
\hline $550 \mathrm{~m}($ Oct 1988) & 0.01 & ND & 48,130 & \\
\hline 550 m (July 1989) & Anoxic & ND & 135 & \\
\hline \multicolumn{3}{|l|}{ Santa Barbara basin } & & Bernhard et al. (1997)> $63 \mu \mathrm{m}, 0-1 \mathrm{~cm}$ \\
\hline $339 \mathrm{~m}$ & 0.51 & 7 & 2,660 & \\
\hline $431 \mathrm{~m}$ & 0.35 & 11 & 34,505 & \\
\hline $522 \mathrm{~m}$ & 0.08 & 10 & 9,430 & \\
\hline $537 \mathrm{~m}$ & 0.04 & 12 & 6,350 & \\
\hline $591 \mathrm{~m}$ & 0.06 & 9 & 19,790 & \\
\hline \multicolumn{3}{|l|}{ Point Conception } & & Shepperd et al. (2007)> $150 \mu \mathrm{m}, 0-1 \mathrm{~cm}$ \\
\hline 990 m (May 1996) & 0.47 & 3 & 188 & \\
\hline 990 m (Aug 1996) & 0.46 & 3 & 308 & \\
\hline 990 m (Oct 1996) & 0.44 & 7 & 246 & \\
\hline \multicolumn{2}{|l|}{ Callao (Perú) } & & & hleger \& Soutar $(1973)>62 \mu \mathrm{m}$, surface sediment \\
\hline $180 \mathrm{~m}$ & ND & $\sim 11$ & $\sim 3,000$ & \\
\hline \multicolumn{2}{|l|}{ Callao (Perú) } & & & Levin et al. (2002)> $150 \mu \mathrm{m}, 0-1 \mathrm{~cm}$ \\
\hline $305 \mathrm{~m}$ & 0.02 & ND & 29,043 & \\
\hline $563 \mathrm{~m}$ & 0.26 & ND & 926 & \\
\hline $831 \mathrm{~m}$ & 0.84 & ND & 497 & \\
\hline $1,211 \mathrm{~m}$ & 1.78 & ND & 96 & \\
\hline \multicolumn{2}{|l|}{ Concepción (Chile) } & & & This study $>180 \mu \mathrm{m}, 0-1 \mathrm{~cm}$ \\
\hline $88 \mathrm{~m}$ (August 2003) & $\sim 0.2$ & 3 & 161 & \\
\hline 120 m (August 2003) & ND & 10 & 198 & \\
\hline $1030 \mathrm{~m}$ (August 2004) & $>2$ & 18 & 96 & \\
\hline
\end{tabular}




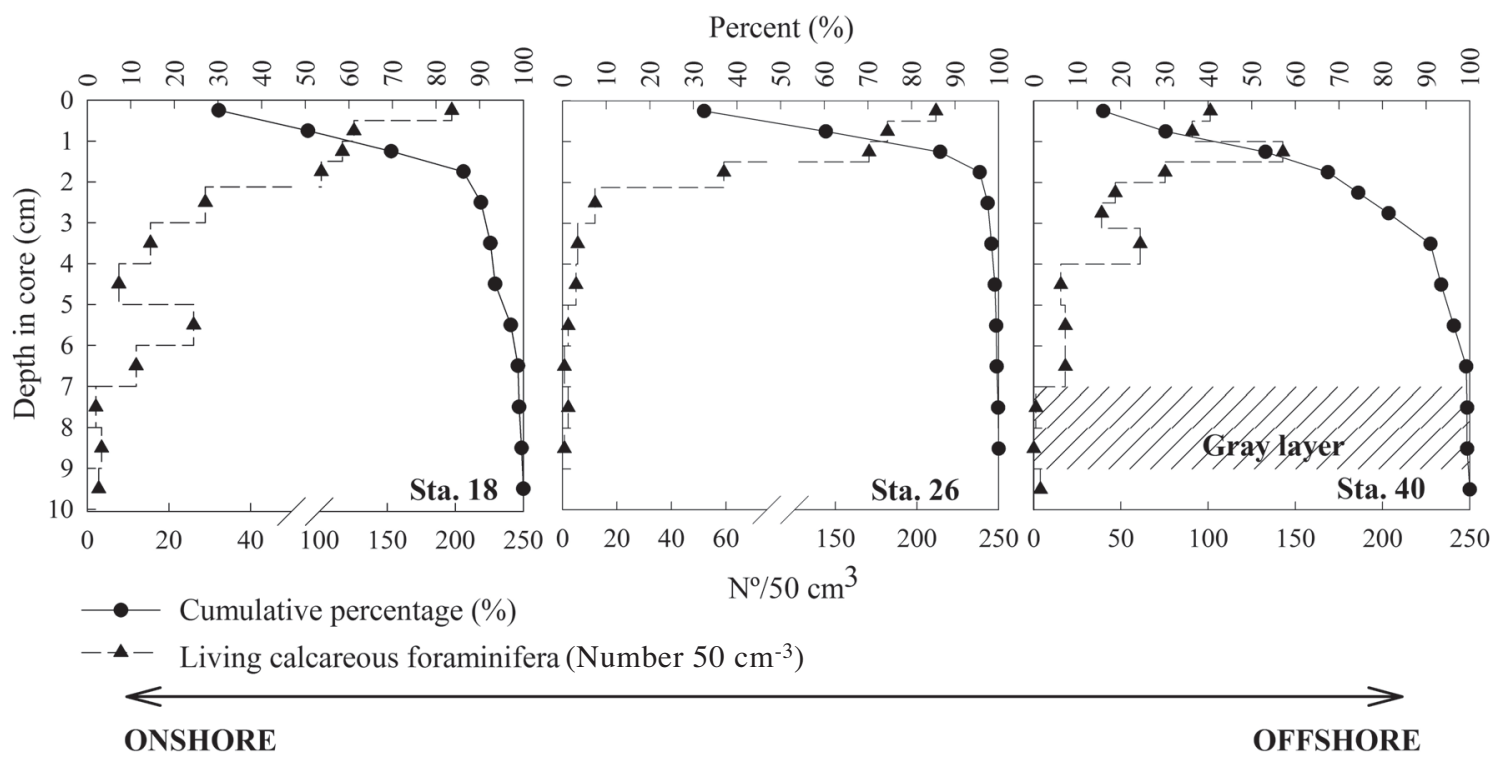

Fig.2: Vertical distribution of total living benthic calcareous foraminifers (Rose Bengal stained, fraction $>180 \mu \mathrm{m}$, standardized to $50 \mathrm{~cm}^{3}$ sediment volume), and cumulative percent of living organisms within the upper $10 \mathrm{~cm}$ of each core.

Distribución vertical de los foraminíferos calcáreos vivos totales (teñidos con Rosa de Bengala, fracción $>180 \mu \mathrm{m}$, estandarizados a $50 \mathrm{~cm}^{3}$ de sedimento) y porcentaje acumulado de organismos vivos dentro de los primeros $10 \mathrm{~cm}$ de cada testigo de sedimento.

\section{DISCUSSION AND CONCLUSIONS}

We are aware that the conclusions we can draw from our study are limited by the reduced sampling occasions and by the size fraction selected ( $>180 \mu \mathrm{m})$, which may have introduced some bias regarding to the abundance of total foraminifers. Nevertheless, these data provide valuable insights into the ecology of foraminifera in the region and the trends indicated by our foraminiferal data may serve as groundwork for future testing.

Despite the methodological differences, our 0-1 cm density data of stained specimens (standardized to $50 \mathrm{~cm}^{2}$ ) are comparable to the values observed off Point Conception, California, by Shepperd et al. (2007) and suboxic slope settings off Callao, Peru, by Levin et al. (2002), who used size fractions > $150 \mu \mathrm{m}$ (Table 6). Our data are lower than those reported for the oxygen-poor Santa Barbara Basin (Bernhard 1990, 1992) and much lower than the Arabian Sea, where densities of tens of thousands of living benthic foraminifera (fractions $>63$ and $150 \mu \mathrm{m}$ ) have been found in surface sediments influenced by low oxygen conditions (Gooday et al. 2000) (Table 6).

According to Sen Gupta \& MachainCastillo (1993), about ten calcareous foraminifer species typically live in oxygenpoor areas, with two or three species usually comprising as much as $80 \%$ of the fauna. In our study, the number of living calcareous species for shelf stations 18 and 26 varied between 3 and 10 (Table 3 and 6); $90 \%$ of the total calcareous living benthic foraminiferal fauna were composed by one species (Table 5). The number of species is similar to that found in the Santa Barbara basin, California, by Phleger \& Soutar (1973) and Bernhard et al. (1997), who reported 7-13 stained species of calcareous foraminifera in the $>63 \mu \mathrm{m}$ fraction (Table 6), and to Peru, where one species (Bolivina cf. pacifica) composes $>95 \%$ of the living fauna (Phleger \& Soutar 1973). In contrast, our data are much lower than those reported for the Oman Margin, where the total number of stained species observed by Gooday et al. (2000) varied between $49(>125 \mu \mathrm{m})$ and 64 (> $63 \mu \mathrm{m})$. 

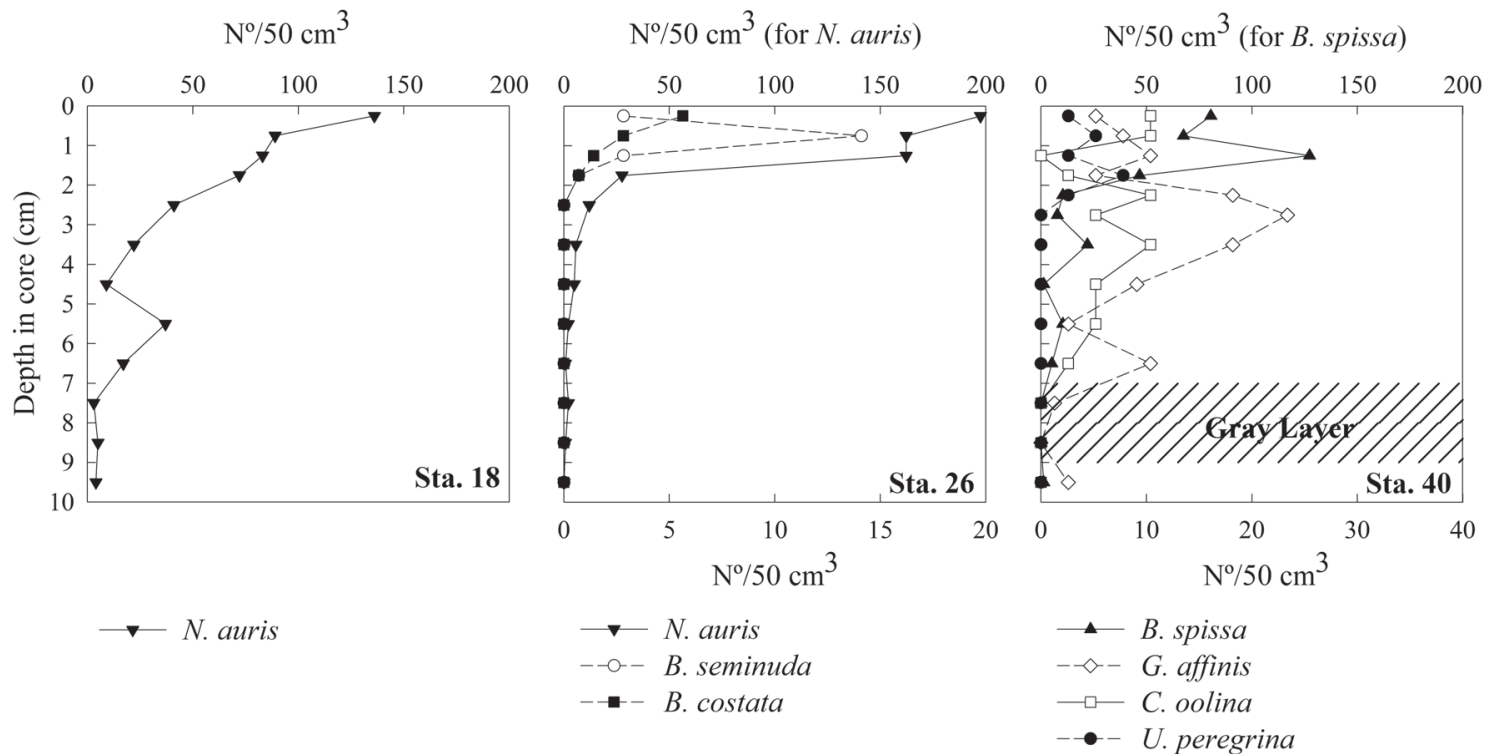

Fig.3: Vertical distribution of the most important taxa of living benthic calcareous foraminifers (Rose Bengal stained, fraction $>180 \mu \mathrm{m}$, standardized to $50 \mathrm{~cm}^{3}$ sediment volume) within the upper $10 \mathrm{~cm}$ of each core.

Distribución vertical de las especies de foraminíferos calcáreos vivos más importantes (teñidos con Rosa de Bengala, fracción $>180 \mu \mathrm{m}$, estandarizados a $50 \mathrm{~cm}^{3}$ de sedimento) dentro de 10 s primeros $10 \mathrm{~cm}$ de cada testigo de sedimento.

Onshore-offshore distribution of living foraminifera

It is well known that benthic foraminiferal abundances in marine sediments are closely related to food availability, and foraminifera generally prosper where food is abundant (Gooday et al. 2000). Along our transect, we detected a decreasing trend in living foraminifera (> $180 \mathrm{~mm}$ ) within the first centimeter with increasing water depth (from 161-198 at stations 18 and 26 to 96 specimens per $50 \mathrm{~cm}^{2}$ at station 40, Table 6). This is most probably induced by lower and less labile organic matter flux reaching the sea floor in deeper settings such as those of Sta. 40 (Schubert et al. 2000, Molina et al. 2004, Muñoz et al. 2004), and/or a reduction in predation pressure at oxygen-depleted settings such as stations 18 and 26 (Gooday 2003). Although available Chl- $\alpha$ and TOC measurements do not coincide with the sampling times for foraminifera, on hand data show that station 40 is generally characterized by lower levels of Chl- $\alpha$ concentrations and TOC $(\sim 13$ $\mathrm{mg} \mathrm{g}^{-1}$ and $<3 \%$, respectively) than the shelf stations (Table 2).
In order to gain access to food, benthic foraminifers must tolerate the oxygen depletion that frequently accompanies abundant organic matter. Reduced oxygen concentrations and/or recurring anoxia events will influence the size distribution and taxonomic composition of foraminiferal assemblages, eliminating the less tolerant species, whereas abundance and dominance increase for the remaining species (Sen Gupta \& Machain-Castillo 1993, Gooday et al. 2000). Our observations are consistent with these concepts, showing minimal presence of large foraminifera and the dominance of a low diversity assemblage in the oxygen-poor conditions of the shallowest stations (18 and 26), which are associated with the upper boundary of the OMZ. Here, the shelf restricted $N$. auris (Resig 1981) (in fraction > $180 \mu \mathrm{m}$, Table 5) composed over $90 \%$ of the total living calcareous foraminifera fauna. A quick scan of the $>63 \mu \mathrm{m}$ fraction revealed that $N$. auris was dominant (data not shown) at these shelf stations and was accompanied by juvenile bolivinids (about $30 \%$ ) at station 26 .

The dominance of $N$. auris at the two stations associated with the OMZ differs from 
observations by Ingle et al. (1980), who found typical OMZ foraminiferal fauna $(>250 \mu \mathrm{m}$ fraction) in central Chile to be primarily composed by bolivinids such as Bolivina seminuda and Bolivina costata. Bolivinids had a minimal presence or were absent in the 180 $\mu \mathrm{m}$ fraction at Sta. 18 and 26 and, as stated above, juveniles were only observed in the $>63$ $\mu \mathrm{m}$ fraction at station 26 . The discrepancy between our data and those of Ingle et al. (1980) may be explained by the fact that bolivinids are commonly associated with stable OMZ conditions (Heinze \& Wefer 1992), which is not the case for our study area with a seasonally variable OMZ (Paulmier et al. 2006). In contrast, the living assemblage observed at station 40 (dominated by B. spissa, $G$. affinis, U. peregrina, $C$. oolina) agrees with the one reported previously by Ingle et al. (1980) at similar water depths.

Vertical distribution of living foraminiferal fauna within the upper sediment column $(10 \mathrm{~cm})$

The relationship of the benthic foraminiferal microhabitat with food availability and oxygenation of the benthic realm has been schematized in a conceptual model by Jorissen et al. (1995). The TROX-model explains that, in oligotrophic environments, species adapted to low organic flux conditions will thrive close to the sediment-water interface in a welloxygenated setting. The low flux of organic matter to the sediment prevents colonization of the deeper sediment layers by infaunal taxa. In eutrophic conditions, on the other hand, where the principal redox front is positioned close to the sediment surface, infaunal taxa are limited to the first millimeters or centimeters of the sediment (Murray 2001); in this case, they have only a limited tolerance for low oxygen conditions.

Faunal penetration is maximal in "mesotrophic" settings because the oxygen penetration is relatively deep and more or less labile food particles are introduced at depth in the sediment by bioturbating macrofauna creating suitable microhabitats for benthic foraminifera (Jorissen 1999, Fontanier et al. 2002). In such environments, the subsurface accumulation of organic matter (Rathburn \& Corliss 1994) and/or grazing on populations of anaerobic bacteria associated with redox boundaries (Fontanier et al. 2002) could explain the microhabitat selection of a given foraminifer.

In general terms, the vertical patterns observed at our stations agree with the TROXmodel. At stations 18 and 26, the living foraminifera are located preferentially near the sediment surface (50 and $60 \%$ of the total living foraminifera within the first centimeter, Fig. 2). Particularly, species tolerant to low oxygen conditions with shallow infaunal microhabitat preferences (Bernhard \& Sen Gupta 1999) at stations 18 and 26 indicate eutrophic conditions. On the other hand, the deepest penetration of foraminiferal fauna at station 40 is more typical of mesotrophic conditions (70\% of total living calcareous foraminifera occur below the first centimeter). Here, an important proportion of the living population is composed of deep infaunal species such as G. affinis $(\sim 22 \%)$ and C. oolina $(\sim 12 \%)$ (Table 5). This general scenario would suggest that BWDO is the main controlling agent at stations 18 and 26, whereas food supply controls the distribution of benthic foraminifera at station 40 .

The extensive vertical distribution of $N$. auris at station 18 , even with a small peak of stained organisms in the 5-6 cm level (Fig. 2), is interesting to note. This feature may have two explanations. On the one hand, it could refer to an artifact of the Rose Bengal method which may have stained the protoplasm of dead foraminifera (Material and Methods section) at this shallow station. On the other hand, it may be explained by the strong seasonal variation in bioturbation affecting the upper $2-5 \mathrm{~cm}$ of the sediment column associated with highly seasonally variable BWDO concentrations and organic matter supply (Muñoz et al. 2007, Table 2). In fact, ${ }^{210} \mathrm{~Pb}$ activity profiles show an average mixed layer depth of $5 \mathrm{~cm}$ at station 18 (Muñoz et al. 2007). An additional factor to the pattern observed at station 18 could include the denitrification capabilities of $N$. cf stella (most probably $N$ auris, according to published photographs, Risgaard-Petersen et al. 2006) which, although pushed deeper down the sedimentary column by bioturbation, would allow them to remain alive.

In summary, our results show that a clear difference exists between shelf stations 18 and 26 which are dominated mostly by one species tolerant to oxygen depletion, and slope station 
40 where oxygen availability and food introduction within the sediment allow the occurrence of shallow and deep infaunal species.

\section{ACKNOWLEDGEMENTS}

We thank the crew of the L/C Kay Kay and the COPAS technicians for the collection of sediment samples, and $\mathrm{S}$. Nuñez (UdeC) for comments during the preparation of this manuscript. Comments and suggestions by Dr. A.E. Rathburn, and two anonymous referees greatly improved the final version of this manuscript. We acknowledge MECESUP UCO0002 for a scholarship to R. Tapia. This work was funded by the FONDAP-COPAS Center (Project No. 150100007).

\section{LITERATURE CITED}

AHUMADA R \& L CHUECAS (1979) Algunas características hidrográficas de la Bahía de Concepción $\left(36^{\circ} 40^{\prime} \mathrm{S} ; 73^{\circ} 02^{\prime}\right)$ y áreas adyacentes. Gayana Miscelanea (Chile) 8: 3-56.

BANDY OL \& KS RODOLFO (1964) Distribution of foraminifera and sediments, Peru-Chile Trench area. Deep-Sea Research 11: 817-837.

BERNHARD JM (1988) Postmortem vital staining in benthic foraminifera: Duration and importance in population and distributional studies. Journal in Foraminiferal Research 18: 143-146.

BERNHARD JM (1990) The ecology of benthic Foraminiferida with emphasis on their distribution in anoxic sediments. PhD thesis, University of California, San Diego, California, USA. 168 pp.

BERNHARD JM (1992) Benthic foraminiferal distribution and biomass related to pore-water oxygen content: central California continental slope and rise. DeepSea Research 39: 585-605.

BERNHARD JM (2000) Distinguishing live from dead foraminifera: methods review and proper applications. Micropaleontology 46: 38-46.

BERNHARD JM \& BK SEN GUPTA (1999) Foraminifera of oxygen-depleted environments. In: Sen Gupta BK (ed) Modern foraminifera: 201-216. Kluwer Academic Publisher, Dordrecht, The Netherlands.

BERNHARD JM, BK SEN GUPTA \& PF BORNE (1997) Benthic foraminiferal proxy to estimate dysoxic bottom-water oxygen concentrations: Santa Barbara basin. Journal in Foraminiferal Research 27: 301 310 .

BOLTOVSKOY E \& F THEYER (1970) Foraminíferos recientes de Chile central. Revista del Museo Argentino de Ciencias Naturales "Bernardino Rivadavia" e Instituto Nacional de Investigación de las Ciencias Naturales Hidrobiología 2: 279-385.

BÖNING P, S CUYPERS, M GRUNWALD, B SCHNETGER \& HJ BRUMSACK (2005) Geochemical characteristics of Chilean upwelling sediments at $\sim 36^{\circ} \mathrm{S}$. Marine Geology 220: 1-21.
BUZAS M, SJ CULVER \& FJ JORISSEN (1993) A statistical evaluation of the microhabitats of living (stained) infaunal benthic foraminifera. Marine Micropaleontology 20: 3-4.

DANERI G, V DELLAROSA, R QUIÑONES, B JACOB, $P$ MONTERO \& O ULLOA (2000) Primary production and community respiration in the Humboldt Current System off Chile and associated oceanic areas. Marine Ecology Progress Series 197: 41-49.

ERSNT SR \& B VAN DER ZWAAN (2004) Effects of experimentally induced raised levels of organic flux and oxygen depletion on a continental slope benthic foraminiferal community. Deep-Sea Research 51: 1709-1739.

ESCRIBANO R \& W SCHNEIDER (2007) The structure and functioning of the coastal upwelling in central/ southern Chile. Progress in Oceanography 75: 343 602.

FIGUEROA S, M MARCHANT, S GIGLIO \& M RAMÍREZ (2005) Foraminíferos bentónicos rotalínidos del centro sur de Chile $\left(36^{\circ} \mathrm{S}-44^{\circ} \mathrm{S}\right)$. Gayana (Chile) 69: 329-363

FIGUEROA $S, M$ MARCHANT, $S$ GIGLIO \& $M$ RAMÍREZ (2006) Foraminíferos bentónicos del talud continental desde Concepción a las Islas Guaitecas (36- $44^{\circ} \mathrm{S}$ ), Chile (Foraminifera: Lagenina, Miolina y Robertinina). Gayana (Chile) 70: 255-279.

FONTANIER C, F JORISSEN, L LICARI, A ALEXANDRE, P ANSCHUTZ \& P CARBONEL (2002) Live benthic foraminiferal faunas from bay Biscay: Faunal density, composition, and microhabitats. Deep-Sea Research 49: 751-785.

GALLARDO VA, M PALMA, FD CARRASCO, D GUTIÉRREZ, L LEVIN \& JI CAÑETE (2004) Macrobenthic zonation caused by the oxygen minimum zone on the shelf and slope off central Chile. Deep-Sea Research 51: 2475-2490.

GOODAY AJ (2003) Benthic foraminifera (Protist) as tools in deep water paleoceanography: environmental influences and faunal characteristics. Advances in Marine Biology 46: 3-70.

GOODAY AJ \& AE RATHBURN (1999) Temporal variability in living deep-sea foraminifera: a review. Earth Science Review 46: 187-212.

GOODAY AJ, JM BERNHARD, LA LEVIN \& SB SUHR (2000) Foraminifera in the Arabian Sea oxygen minimum zone and other oxygen-deficient settings: taxonomic composition diversity, and relation to metazoan faunas. Deep-Sea Research 47: 25-54.

GUTIÉRREZ D (2000) Bioperturbación y macrofauna en fondos sublitorales de un área de surgencias frente a Chile central $\left(36^{\circ} 30^{\prime} \mathrm{S}\right)$ : variación espacial y temporal en el periodo 1997-1999. PhD thesis, Universidad de Concepción, Concepción, Chile. 221 pp.

GUTIÉRREZ D, VA GALLARDO, S MAYOR, C NEIRA, C VÁSQUEZ, J SELLANES, M RIVAS, A SOTO, F CARRASCO \& M BALTAZAR (2000) Effects of dissolved oxygen and fresh organic matter on the bioturbation potencial of macrofauna in sublittoral bottoms off central Chile, during the 1997-1998 El Niño. Marine Ecology Progress Series 202: 81-99.

HEINZE PM \& G WEFER (1992) The history of coastal upwelling off Peru $\left(11^{\circ} \mathrm{S}\right.$, ODP Leg 112 , Site $\left.680 \mathrm{~B}\right)$ over the past 650.000 years. In: Summerhayes CP, WL Prell \& KC Emeis (eds) Upwelling systems: evolution since the early Miocene: 451-462. Geological Society Special Publications 64, Geological Society, London, United Kingdom. 
HELLY J \& L LEVIN (2004) Global distribution of naturally occurring marine hypoxia on the continental margins. Deep-Sea Research 51: 11591168 .

HROMIC T, S ISHMAN \& N SILVA (2006) Benthic foraminiferal distributions in Chilean fjords: $47^{\circ} \mathrm{S}$ to $54^{\circ} \mathrm{S}$. Marine Micropaleontology 59: 115-134.

INGLE JC, G KELLER \& RL KOLPACK (1980) Benthic foraminiferal biofacies, sediments and water mass of the southern Peru-Chile trench area, southeastern Pacific Ocean. Micropaleontology 26: 113-150.

JORISSEN FJ (1999) Benthic foraminiferal microhabitats. In: Sen Gupta BK (ed) Modern foraminifera: 161179. Kluwer Academic Publisher, Dordrecht, The Netherlands.

JORISSEN FJ, HC STIGTER \& JG WIDMARK (1995) A conceptual model explaining benthic foraminiferal microhabitats. Marine Micropaleontology 26: 3-15.

LEVIN L, J GAGE, C MARTIN \& P LAMONT (2000) Macrobenthic and community structure within and beneath the oxygen minimum zone, NW Arabian Sea. Deep-Sea Research II 47: 189-226.

LEVIN L, D GUTIÉRREZ, AE RATHBURN, C NEIRA, J SELLANES, P MUÑOZ, VA GALLARDO \& MA SALAMANCA (2002) Benthic processes on the Peru margin: a transect across the oxygen minimum zone during the 1997-1998 El Niño. Progress in Oceanography 53: 1-27.

MOLINA V, L FARÍAS, M GRACO, C RIVERA, L PINTO \& VA GALLARDO (2004) Benthic nitrogen regeneration under oxygen and organic matter spatial variability off Concepción $\left(\sim 36^{\circ} \mathrm{S}\right)$, central Chile. Deep-Sea Research 51: 2507-2522.

MUÑOZ P, CB LANGE, D GUTIÉRREZ, D HEBBELN, MA SALAMANCA, L DEZILEAU, JL REYS \& LK BENNIGER (2004) Recent sedimentation and mass accumulation rates based on ${ }^{210} \mathrm{~Pb}$ along the Peru-Chile continental margin. Deep-Sea Research 51: 2553-2541.

MUÑOZ P, J SELLANES, CB LANGE, M PALMA \& MA SALAMANCA (2007) Temporal variability of ${ }^{210} \mathrm{~Pb}$ fluxes in shelf sediments beneath the high primary production are off Concepción, centralsouthern Chile $\left(36^{\circ} \mathrm{S}\right)$. Progress in Oceanography 75: $586-602$

MURRAY JW (2001) The niche of benthic foraminifera, critical thresholds and proxies. Marine Micropaleontology 41: 1-7.

NEIRA C, J SELLANES, A SOTO, D GUTIÉRREZ \& VA GALLARDO (2001) Meiofauna and sedimentary organic matter off Central Chile: response to changes caused by the El Niño. Oceanologica Acta 24: 134-328.

PAULMIER A, D RUIZ-PINO \& L FARÍAS (2006) Maintaining of the eastern South Pacific Oxygen Minimun Zone (OMZ) off Chile. Geophysical Research Letters 33: 601-612.

PHLEGER FB \& A SOUTAR (1973) Production of benthic foraminifera in three east Pacific oxygen minima. Micropaleontology 19: 110-115.

PIZARRO O, G SHAFFER, B DEWITTE \& M RAMOS
(2002) Dynamics of seasonal and interannual variability of the Peru-Chile undercurrent. Geophysical Research Letters 29: 1-4.

RATHBURN AE \& BH CORLISS (1994) The ecology of living (stained) deep-sea benthic foraminifera from the Sulu Sea. Paleoceanography 9: 87-150.

RESIG JM (1981) Biogeography of benthic foraminifera of the northern Nazca plate and Adjacent continental margin. Geological Society of America Memoir 154: 619-664

RISGAARD-PERTERSEN N, A LANGEZAAL，S INGVARDESEN, M SCHMIDM, M JETTEN, H DEN CAMP, J DERKSEN, E PIÑA-OCHOA, S ERIKSSON, L NIELSEN, N REVSBECH, T CEDHAGEN \& GJ VAN DER ZWAAN (2006) Evidence for complete denitrification in a benthic foraminifer. Nature 443: 93-96.

SEN GUPTA BK \& ML MACHAIN-CASTILLO (1993) Benthic foraminifera in oxygen-poor habitats. Marine Micropaleontology 20: 183-201.

SCHRÖDER CJ, DB SCOTT \& FS MEDIOLI (1987) Can smaller benthic foraminifera be ignored in paleoenvironmental analyses? Journal of Foraminiferal Research 17: 101-105.

SHAFFER G, S HORMAZÁBAL, O PIZARRO \& S SALINAS (1999)ÄSeasonal and interannual variability of currents and temperature off central Chile. Journal Geophysical Research 104: 29951 29961.

SHEPPERD AS, AE RATHBURN \& ME PÉREZ (2007) Living foraminiferal assemblages from the Southern California margin: A comparison of the $>150,63$ 150 , and $>63 \mu \mathrm{m}$ fractions. Marine Micropaleontology 65: 54-77

SHUBERT CJ, TG FELDERMAN \& B STROTMAN (2000) Organic matter composition and sulfate reduction rates in sediments off Chile. Organic Geochemestry 31: 351-361

SOBARZO M (1993) Caracterización de la circulación de Bahía Concepción, Chile: un análisis temporal en el dominio de la frecuencia. MSc thesis, Universidad de Concepción, Concepción, Chile. 128 pp.

SOBARZO M, D FIGUEROA \& L DJURFELDT (2001) Upwelling of subsurface waters into the rim of the Biobío submarine canyon as a response to surface winds. Continental Shelf Research 21: 279-299.

TAPIA R (2003) Variación de la intensidad de la mínima de oxígeno en los últimos 200 años, estudiada mediante foraminíferos bentónicos en la plataforma continental de Chile central $\left(36^{\circ} \mathrm{S}\right)$. Undergraduate thesis, Universidad de Concepción, Concepción, Chile. 53 pp.

VAN DER ZWAAN GJ, IAP DUIJNSTEE, M DEN DULK, SR ERNST, NT JANNINK \& TJ KOUWENHOVEN (1999) Benthic foraminifers: proxies or problems? A review of paleocological concepts. Earth Science Review 46: 213-236.

ZAPATA J \& H MOYANO (1997) Foraminíferos bentónicos recientes de Chile austral. Gayana Zoología (Chile) 68: 27-37. 